Research Paper

\title{
Global-Local Dynamics in Urbanization: The transformation of the desa-kota in Bali and the roles of adat institutions
}

\author{
B. Setiawan \\ Graduate Program in Urban and Regional Planning Gadjah Mada University, \\ Jl. Grafika 2 Sekip, Yogyakarta Indonesia \\ e-mail: bobi.setiawan@ugm.ac.id/bobi.setiawan@gmail.com \\ Sita Rahmani \\ Graduate Program in Urban and Regional Planning Gadjah Mada University, \\ Jl. Grafika 2 Sekip, Yogyakarta Indonesia \\ e-mail: bobi.setiawan@ugm.ac.id/bobi.setiawan@gmail.com
}

\begin{abstract}
For so long, urban studies in developing regions such as Indonesia has been trapped into a single view of global value and capital as the main, powerfull forces of the process. The result is therefore, a global, universal form or urbanization and the production of urban spaces. The fact that cities each have different histories, heritage, and resources show that there are local variations in response to global-economic pressures. With a case study of the transformation of the desa-kota in Bali, Indonesia, this paper shows and argues that in the dynamics process of urbanization, local actors and forces have play a significant roles in the production of urban spaces. Further, it argues that the existing centralized-Indonesia 'formal/legal' urban policy and planning system does not fit with the existing dynamics of local-cultural variations of urbanization - the roles of adat institutions and nomrs are significant and therefore should be supported and facilitated.
\end{abstract}

\section{Keywords}

desa-kota, transformation, local-global dynamics, adat institution, Bali

\section{Introduction}

\subsection{Urbanization and Urban Growth in Indonesia: Questioning the Desa-Kota Idea}

With the rapid level of urbanization and urban growth, the sustainability and the quality lives of the majority of the Indonesian population will depend on the quality of the urban environment. Based on the data of the Central Bureau of Statistics Indonesia (BPS, 2013), in 2010, the rate of urbanization in Indonesia is 49.8 percent. Recently, more than half the residents of Indonesia $(53,3 \%)$ reside in urban areas. In 2025 , with the total population of around 273 million, approximately 68 percent of them will be living in urban areas. Such rapid urbanization rate which is then manisfestated in the rapid growth of the city should be 
anticipated with good planning and appropriate management in order to guarantee its sustainability.

This current status and future projection of urbanization in Indonesia brings two related aspects. First, urbanization and urban growth will facilitate the improvement of the quality of life and the environment of a large part of Indonesia society - something that we all hope. Second, however, this rapid urbanization phenomenon could increasingly perpetuate many problems that are already exist, and even leads to the worsening quality of the urban environment and urban communities - the sustainability of the city and its residents is questioned. There is a crucially need for a better and appropriate planning effort to guide rapid urbanization and urban groiwth in Indonesia.

The theory and the concept of the kota-desa were firstly promoted by McGee (1991). It was to explain the phenomenon of the development of suburban areas of Asian countries, including Indonesia. The basic argument is that the process and the product of urbanization in Asian countries is not similar to that in Western countries. In particular, this concept refers to the processes, forms and characteristics of the sub-urban settlements. It describes that such area has already some urban characteristics, but at the same time, still retain the characteristics of the rural environment and life. Further, this concept explains the stages of the development of urban areas on the sub-urban or outskirts of the city that are not entirely planned and managed, and tend to be organic. Physicaly, the concept of desa-kota manifestated in the form spatial transformation, a complexd and dynamic mix between urban and rural elements. Socially, culturally, and economically, the concept also explains an interesting, complex, and dynamic mixed and interaction between urban and rural activities, between modern and traditional institutions, and between formal and informal mechanisms.

Since its birth, the desa-kota concept tends to be used to describe the phenomenon or development model of Indonesian cities and also Southeast Asian cities - it is a kind of descriptive model. In spite of some criticisms, the concept is increasingly accepted as a relevant concept to understand the processes, forms and characteristics of the development of Indonesian cities. Under the challenges and the need for a more better and appropriate planning approach to guide urban development in Indonesia, it would be very challenging to explore the possibilities of such concept for a more prescriptif ones. A preliminary study done in Yogyakarta in 2014 (Harmen et.all. 2014) shows that the desa-kota in Yogyakarta has a range of distinctive characteristics and contains aspects that in accordance with the principles and indicators of sustainability.

\subsection{Urbanization and Urban Grwoth in Bali: Problems or Challenges}

Up to now, various studies and writings have been done on Bali, the paradise island, famous as the largest tourist destination in Indonesia. With the beauty of nature, traditions, culture, and history, Bali is called as the island of the gods, that offers exceptional beauty. Traditional settlements in Bali, for example, has very clear concepts and principles that are a balance and harmonious interactions between man and nature (Budiharjo, 1987). The very rapid development of tourism, however, is increasingly brought pressures and problems to the beauty of Bali. As have been documented by several studies, various environmental, social, and economic problems have appeared in Bali and threatening her sustainability (Martopo and Mitchell, 1995).

According to data from BPS (2013), the level of urbanization in Bali is currently around 56 percent. This means that about 1.7 million inhabitants of Bali resided in urban areas. It is also already projected that by 2025, the urban population will increase to about 2 millions. 
Such significant increase should be appropriatelly respond to make sure the sustainability of Bali.

Geographically, the urbanization in Bali is concentrated in the city of Denpasar, which has more access to various economic centers and tourism attractions in Bali. In 2013, the city of Denpasar has only 789,000 , population, and it is projected that it will become 1.2 million in the year 2020. This figure includes the whole urbanized areas of Denpasar, known as metropolitan of Sarbagita, consists of Denpasar, some parts of Badung and Gianyar. This rapid development has penetrated the villages on the outskirts of Denpasar which some are traditional Balinese villages. The expansions of urban areas in the tradional Balinese villages are crucially important phenomena which should be explored and documented. It is with the assumptions that such case may constitute best practices of rural-urban settlements, which can be learned and then further develop as a descriptif model of rural-urban settlements in the future.

\subsection{The Objectives of the Paper}

Based on the background presented above, this goal of this research is to explore and document the desa-kota phenomena in Bali, which is belived to be a unique and may contains some important elements and principles of sustainable urban settlement. Such general goal could then be elaborated into three objectives, which are: 1)

To document the best practices of three types of rural-urban settlements in Bali;

2) To examine their sustainability as well as the factors that determine the sustainability; and 3) to develop a planning model to guide the future development of the desa-kota settlement in Bali.

This research was conducted with deskritif analytical approach, whereby the three cases studied were explored and analyzed with a set of indicators. The indicator used is determined through a review of the literature and discussed with stakeholders in the three cases examined. From here, the level of sustainability can be measured in three cases. Further, it then analyzed factors that determine the sustainability of the three cases. From such process then, lessons learned could be then generated. In order to achieve such objectives severalmethods were used in the reserach which included: field surveys, interviews, as well as FGD with stakeholders in three villages. Further, secondary data were also collected, particularly related to aspects of sustainability in three cases.

\section{Revisiting The Desa-Kota Ideas}

The concepts and terminology of the desa-kota, firstly promoted by Terry Mc. Gee, an expert on urbanization and urban areas in Asia, in the mid 1980s (McGee, 1987). McGee used the term kotadesasi, to explain the phenomenon of the development of the city in the Asian country, particularly the Southeast Asia countries, which shows difference process and products compare to that of cities in Western countries. This concept specifically describes the process, form, and character development in the suburb area which was originally a rural area. The developmental process of the city that are not fully planned and managed resulted in a mixture of between urban and rural environments. Such unique spatial formation is complicated with a dynamic mix between urban and rural activities. Such processes then produces a distinctive settlement characteristic. 
Although Gottman already explained the unnique phenomena of a megalopolis city in 1960s, McGee argues that the concept of kotadesasi is not the same as a Megalopolis concept. He stated that: "The megalopolis is a region dominated by the activities of the central urban system. In many Asian countries, the process of Kotadesasi is somewhat different, for it is occuring in many different locations often in areas adjacent to fairy-giants of the urbans cities and sometimes in the form of corridor development adjacent to main roads or railways that link reasonably close, large cities."

Further, he explained that the growth of megalopolis will form special elements namely: 1) a big city; 2) suburban areas; 3) rural-urban; 4) high population density village; 5) low population density village; and 6) small town. This process is characterized by the change of the village became a city, which was accompanied by a shift in economic activity into the formal informal. Example of a megalopolis in Indonesia, among others, is Jabodetabekjur (Jakarta, Bogor, Depok, Bekasi, Cianjur). He, however, also explained how the entire Java island can also be referred to as a series of large megalopolis. The ide of kotadesasi is then used to explain the development of metropolitan cities like Jabodetabekjur, referred to as the Extended Metropolitan Region - EMR. Some characteristics of EMR are: 1) high population density); 2) most of the population depends on agriculture; 3) undergoes transformation activities from agriculture to non farm activities (trade, transport and industry); 4) the intensity of a high population mobility possible availability of transportation is cheap; 5) high interaction between rural and urban activity; and 6) mixing of intensive land use between settlements and economic activities, such as agricultural, industrial, household and industrial areas.

Later, the concept of kotadesasi was then used by many researchers to investigate the phenomenon of urbanization and urban growth in various Asian countries. These studies confirm this concept (Guldin, 1997; The Desakota Study Team, 2008; Moench and Gyawali, 2008). One among studies concerning the desa-kota idea has resulted in nine parameters of to be used to asess the desa-kota, as can be seen in the Table below.

Table 1. The Desa-Kota Parameter

\begin{tabular}{|c|c|c|}
\hline No & Parameter & General Condition of Three Cases \\
\hline 1. & Access to the city & $\begin{array}{l}\text { This network enables connectivity between villages and } \\
\text { cities, either to support the activities of the economic and } \\
\text { social }\end{array}$ \\
\hline 2. & $\begin{array}{l}\text { Job opportunities in second and } \\
\text { tertiary sector }\end{array}$ & $\begin{array}{l}\text { Allow the villagers, including woman to acess job and } \\
\text { income, without having to leave her village/familly }\end{array}$ \\
\hline 3. & Access to outside world & $\begin{array}{l}\text { The network of communication that allow villagers } \\
\text { associated with the outside society actively, both national } \\
\text { and global }\end{array}$ \\
\hline 4. & $\begin{array}{l}\text { Most household engage in both } \\
\text { farming and non-farming } \\
\text { activities/labour }\end{array}$ & $\begin{array}{l}\text { The villagers have a double income from farming activities } \\
\text { and non-agriculture }\end{array}$ \\
\hline 5. & $\begin{array}{l}\text { There is still local/traditional } \\
\text { group }\end{array}$ & $\begin{array}{l}\text { Provide opportunities to maintain traditional norms, } \\
\text { including a spirit of social works and togetherness; strong } \\
\text { social capital }\end{array}$ \\
\hline
\end{tabular}




\begin{tabular}{|c|l|l|}
\hline 6. & Access to Modern technology & $\begin{array}{l}\text { Enable local communities to respond global/modern } \\
\text { opportunities; Start available modern technologies for } \\
\text { processing agricultural and non-agricultural products }\end{array}$ \\
\hline 7. & Contractual works is exist & $\begin{array}{l}\text { Direct wages/cash economy quite dominant, though still } \\
\text { tend to be informal sector }\end{array}$ \\
\hline 8. & $\begin{array}{l}\text { Mixed on rural and urban } \\
\text { institution }\end{array}$ & $\begin{array}{l}\text { Enable local communities to maintain both traditional and } \\
\text { modern activities }\end{array}$ \\
\hline 9. & Link to global market & Getting connected with the global economy \\
\hline
\end{tabular}

Source: Adopted from The Desakota Study Team (2008)

\section{Description Of Research Area}

Bali represents the most important tourist destination of Indonesia (Cole, 2012). Located eight degree of equator, Bali has warm temperatures which draws more than 3.5 million tourists in 2014 Tourism in Bali has been relying on the cultural activities and beaches (Rajendra and Nicholls, 2014). Hindu is the main religion in Bali. Its culture is strongly embodied in ceremonies, everyday rites, and temple festivals (Tang, 2004). Natural resources have been very important for this $5,636.66 \mathrm{~km} 2$ island, for example coastal resources, agriculture, mining, and forest (Rajendra and Nicholls, 2014). Bali's main concept of development in 1970s was culture-based tourism development supported by agricultural activities (Sudaratmaja, 2010). Having relatively small area combined with high number of population, for about 4 million people in 2015, land conversions have been unbearable to occur. Land conversion has been a high demand for tourism development, mainly at Badung Regency, Gianyar Regency, and Denpasar City.

Land conversion in Bali has been occurred in average 380-400 ha per year in the last 12 years (Bali Environmental Agency, 2015). The highest record was set during 1987-2003. In average 1,000 ha open land per year was converted into built-up land. The number has actually declined in 2010-2014 that was 338 ha per year land conversion. Paddy field is relatively more in favor for investor than dry land because its equipped infrastructure, for example irrigation canal, street, bridge, market, and information system (Sudaratmaja, 2010). 


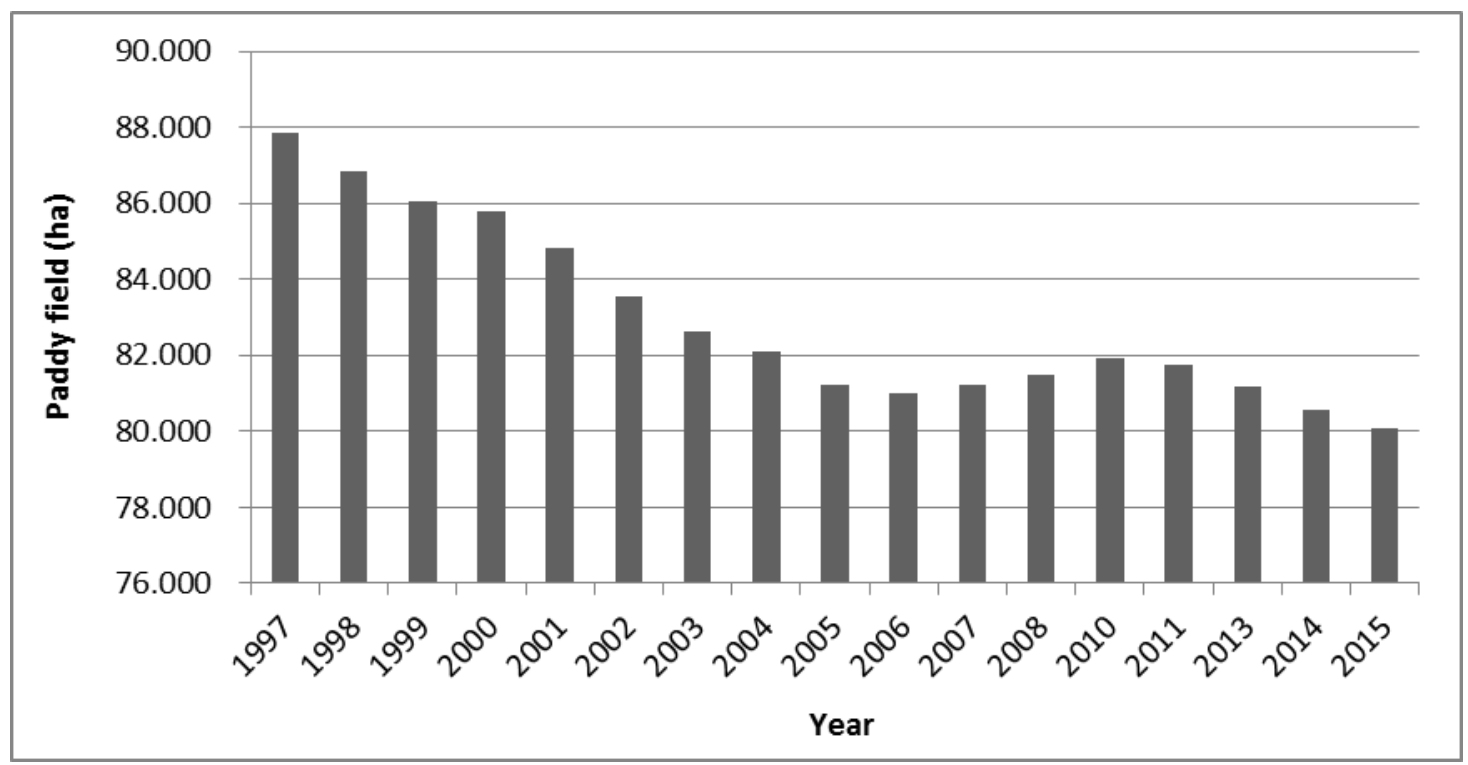

Figure 1. Land Conversion in Bali 1997-2015

Source: Bali Environmental Agency (2015) and Sudaratmaja (2010)

Bali Employment Statistic (2016) stated that in 2015, 56.12\% employee in Bali works in service sector, and followed by $24.43 \%$ and $24.02 \%$ of agricultural sector and manufacture. In Denpasar City, tertiary sector has absorbed major employment, that are trading-hotelrestaurant (39.55\%), service sector (24.02\%), and industry (13.29\%). Work opportunities in Denpasar City have drawn people from other regions, particularly rural area. The good quality of road infrastructures has made Denpasar accessible and relatively close to commute every day. Three cases of desa-kota, that are Lebih Village, Jagapati Village, and Pejaten Village, have different distances and traveling times.

Table 1. Distance from Three Villages to Denpasar City

\begin{tabular}{|l|c|c|}
\hline \multicolumn{1}{|c|}{ Village } & Distance to Denpasar & Traveling time to Denpasar \\
\hline 1. Lebih & $20 \mathrm{~km}$ & 45 minutes \\
\hline 2. Jagapati & $15 \mathrm{~km}$ & 33 minutes \\
\hline 3. Pejaten & $30 \mathrm{~km}$ & 1 hour and 4 minutes \\
\hline
\end{tabular}

Source: village book profile (2016) 


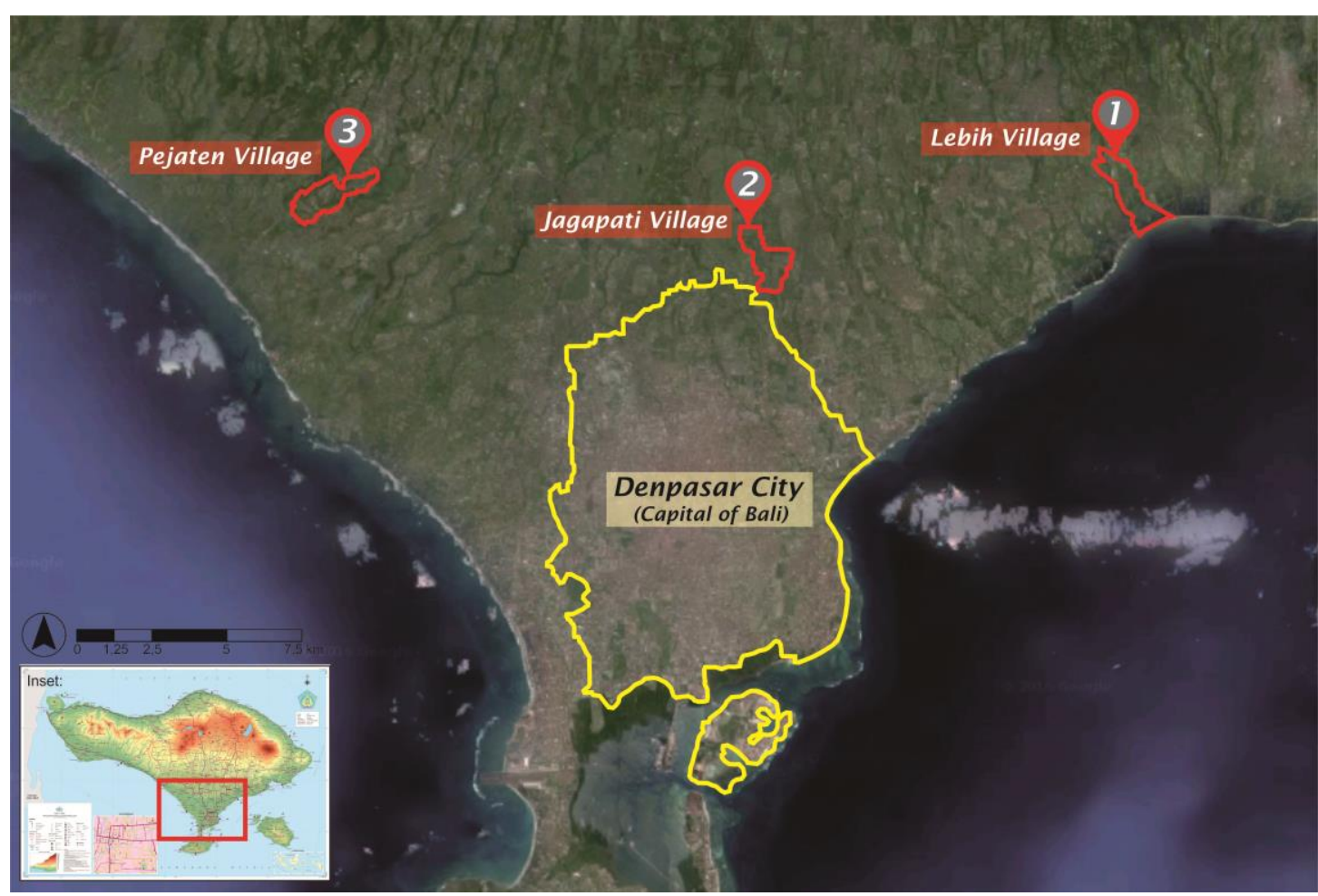

Figure 2. The study area

Source: Google map and analysis (2016)

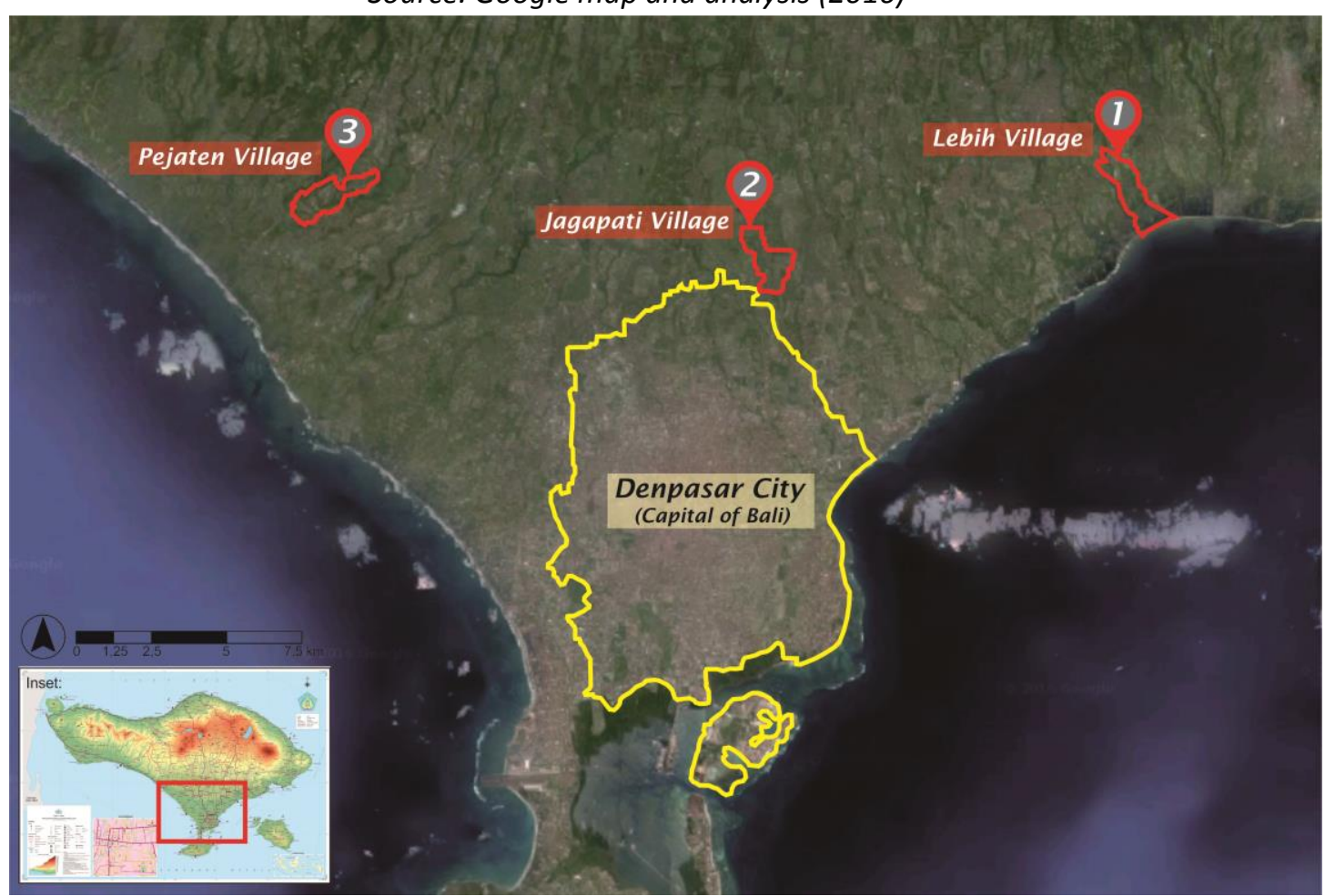

Figure 2. The study area

Source: Google map and analysis (2016)

Descriptions of Three Case Studies/Villages 
The reserach has been able to identify several characteristics of the three villages that distinguishes one with the other. This characteristic is important to be understood and documented because it will be the basis of the development of three villages in the future. The following table summarizes the characteristics of the three villages that were examined.

Table 2. Description of Three Villages

\begin{tabular}{|c|c|c|c|}
\hline $\begin{array}{c}\text { DIMENSIO } \\
\mathrm{N}\end{array}$ & $\begin{array}{c}\text { Village: Lebih, } \\
\text { Gianyar }\end{array}$ & $\begin{array}{c}\text { Village: Jagapati, } \\
\text { Badung }\end{array}$ & $\begin{array}{c}\text { Village: Pejaten, } \\
\text { Tabanan }\end{array}$ \\
\hline $\begin{array}{l}\text { Physic/ } \\
\text { environm } \\
\text { ental } \\
\text { dimension } \\
\text { S }\end{array}$ & $\begin{array}{l}\text { - Unique landscape, a } \\
\text { combination of hilly } \\
\text { areas and coastal areas } \\
\text { - Under pressures of } \\
\text { new regional } \\
\text { road/bypass: land } \\
\text { conversion; } \\
\text { - Traditional settlements } \\
\text { and housing is still } \\
\text { preserve, including } \\
\text { agricultural lands }\end{array}$ & $\begin{array}{l}\text { - Environmentally sensitive, } \\
\text { yet fertile areas in between } \\
\text { two rivers; } \\
\text { - Paddy fields still dominant } \\
\text { and preserved; } \\
\text { - Divided by regional road, } \\
\text { but not significantly give } \\
\text { pressures; } \\
\text { - Traditional settlement is } \\
\text { still preserved }\end{array}$ & $\begin{array}{l}\text { - A fertile geographical unit } \\
\text { - Paddy fields, which are } \\
\text { spacious and dominant, } \\
\text { mixed with clay industry } \\
\text { are tourism potential. }\end{array}$ \\
\hline $\begin{array}{l}\text { Socio- } \\
\text { cultural }\end{array}$ & $\begin{array}{l}\text { - Traditional practices } \\
\text { are still strong; } \\
\text { - New urban/tourism } \\
\text { activities }\end{array}$ & $\begin{array}{l}\text { - Traditional practices are } \\
\text { still strong; } \\
\text { - New/modern activities exist } \\
\text { in limited ways }\end{array}$ & $\begin{array}{l}\text { - Traditional practices are } \\
\text { still strong; } \\
\text { - Some villagers engage in } \\
\text { tourism sectors/activities; } \\
\text { - Start to become small } \\
\text { tourism destination }\end{array}$ \\
\hline Economy & $\begin{array}{l}\text { - Mostly still depends on } \\
\text { agricultural and fishery } \\
\text { sectors; } \\
\text { - Local economy is still } \\
\text { dominant; } \\
\text { - Tourism sector is } \\
\text { increasing }\end{array}$ & $\begin{array}{l}\text { - Mostly still depends on } \\
\text { agricultural sector; } \\
\text { - Increasing number of } \\
\text { villagers work in modern } \\
\text { sectors (public and private) }\end{array}$ & $\begin{array}{l}\text { - Mostly depends on SMEs; } \\
\text { - Increasing number of } \\
\text { villagers engage in modern } \\
\text { sectors. }\end{array}$ \\
\hline
\end{tabular}

Source: analysis (2016)

It can be summarized from the study that the three villages have characteristics that are fairly typical, although not too special. From physical point of views, for example, each village has its own unique which could be developed into a beautiful and unique residential and landscape. It particularly has an interesting blend of natural and human-made environment. It could then appreciated as a unique and interesting cultural landscape.

However, despite their uniquesness, the study also documented transformation processes that happen slowly. Such transformations, if not guided, could slowly erode and undermine the values landscape of the villages. As will be further expalin in this paper, the changing landscape of these villages have caused by some modern/government projcests, including, bypass, embankment of the beach along the waterfront, as well as the construction of a variety of commercial and tourist facilities. In the case of the village of Jagapati, the existing 
landscape has not occurred in large scales, except for the case of the construction of a new residential complex by developer which then adding elements of the urban landscape in the village setting. In the case of Pejaten, the changes happened due to the exploitation of clay for the raw material of tile and pottery which is quite massive. This process is even triggered some landslides in several areas, caused some casualties.

\section{Research Finding And Discussions}

\subsection{Three cases based on Desa-kota Parameters}

As has been stated in the previous section, McGee has stated that desa-kota settlement could be evaluated through at least nine parameters, consists of physical, social, and economic dimessions. An assessment of the three cases studied in this research reveals that these three cases meeting the parameters and criteria stated in the literature. As can be seen in the Table 3 below, with a slightly different conditions, all three cases meeting the criterias as desa-kota settlements according to Mc.Gee.

From spatial points of views, these three cases have relativelly good and efficient access to the at least two cities. All three cases have access to the main/major city in the region, Denpasar. Case 1, Lebih also has access to the nearby city of Gianyar, Jagapati also has access to a famous town of Ubud, while Pejaten has also access to a growing city of Tabanan. Such good and efficent access to these three cities, open local communities in three villages to commute daily from their village for many economic, social, and even cultural activities.

Table 3. The Three Case According to the Desa-Kota Parameters

\begin{tabular}{|c|c|c|}
\hline No & Parameter & General Condition of Three Cases \\
\hline 1. & Access to the city & $\begin{array}{l}\text { All three villages have good access to the city and other } \\
\text { urban/economic centers }\end{array}$ \\
\hline 2. & $\begin{array}{l}\text { Job opportunities in } \\
\text { second and tertiary sector }\end{array}$ & $\begin{array}{l}\text { All three villages offer job opportunities in primary, secondary, and } \\
\text { tertiary sector - mixed of job opportunities open for village } \\
\text { residents; }\end{array}$ \\
\hline 3. & Access to outside world & $\begin{array}{l}\text { All three villages have a good access to outside world, through } \\
\text { many kinds of IT }\end{array}$ \\
\hline 4. & $\begin{array}{l}\text { Most household engage in } \\
\text { both farming and non- } \\
\text { farming activities/labour }\end{array}$ & $\begin{array}{l}\text { Most of village residents in three cases have a mixed-income/jobs, } \\
\text { farming and non-farming }\end{array}$ \\
\hline 5. & $\begin{array}{l}\text { There is still } \\
\text { local/traditional group }\end{array}$ & $\begin{array}{l}\text { Traditional institution (Adat) is still exist and strong/effective in } \\
\text { three villages }\end{array}$ \\
\hline 6. & $\begin{array}{l}\text { Access to Modern } \\
\text { technology }\end{array}$ & $\begin{array}{l}\text { Tend to uses traditional technology (in farming, industry, and } \\
\text { trading }\end{array}$ \\
\hline 7. & Contractual works is exist & $\begin{array}{l}\text { cash economy tends to be dominant, sector informal is still } \\
\text { important }\end{array}$ \\
\hline 8. & $\begin{array}{l}\text { Mixed on rural and urban } \\
\text { institution }\end{array}$ & $\begin{array}{l}\text { Balance mixed between traditional and modern institution (desa } \\
\text { dinas and desa adat; bank etc.) }\end{array}$ \\
\hline
\end{tabular}


\begin{tabular}{|l|l|l|}
\hline 9. & Link to global market & More connected to global market, particularly Lebih village
\end{tabular}

Source: analysis (2016)

\subsection{Sustainability Assesssment}

A qualitative assessment based on FGD and various other informations has revelead that in general, the three villages could be categorized as those which shows some elements of sustainability. As can be seen in the Table 4 below, the sustainability prospect of the three villages is quite good. This general conclusion is very important because it can be used as the basis for further efforts to enhance the prospect of sustainability of the three villages.

Table 4. The Sustainability of Three Villages

\begin{tabular}{|l|l|l|l|}
\hline \multicolumn{1}{|c|}{ Main Indicators } & \multicolumn{1}{|c|}{ Lebih } & \multicolumn{1}{|c|}{ Pejaten } \\
\hline 1. Food Security And Sovereignty & +++ & +++ & + \\
\hline 2. Poverty/Vulnerability & + & + & + \\
\hline 3. Welfare/Happiness & +++ & ++ & +++ \\
\hline 4. The Role of Traditional Institutions & ++++ & ++++ & ++++ \\
\hline 5. Identity/Proudness & +++ & +++ & +++ \\
\hline 6. Quality of Landscape & ++ & ++ & +++ \\
\hline
\end{tabular}

Source: qualitatif assessment from FGD, interviews, and secondary information (2016)

The above table indicates that there are quite a lot of positive factors that play a role in ensuring sustainability of the three villages. Of the three pillars of sustainable development that are physical/environmental, social, and economic, all three villages have generally had a positive factors to maintain the condition and prospects of sustainability in three villages.

\subsection{Factors Contributed to Sustainability of Three Villages}

The study also identify factors that affect the condition and prospects of sustainability. Through a qualitatif assessment based on FGD, interviews with stakeholders, as well as the data collected, it can be summarised in the following table. The following table summarizes the various factors according to three pillars of sustainable concepts that are physical aspect/environment, social, and economic issues.

Table 5. Factors Contributed to Sustainability of Three Villages

\begin{tabular}{|c|c|c|c|}
\hline DIMENSION & $\begin{array}{c}\text { Village: Lebih, } \\
\text { Gianyar }\end{array}$ & $\begin{array}{c}\text { Village: Jagapati, } \\
\text { Badung }\end{array}$ & $\begin{array}{c}\text { Village: Pejaten, } \\
\text { Tabanan }\end{array}$ \\
\hline $\begin{array}{l}\text { Physical/ } \\
\text { Environment }\end{array}$ & $\begin{array}{l}\text { - Fertile land; } \\
\text { - Water availability; } \\
\text { - Open access to sea; } \\
\text { - Topograhy/steep } \\
\text { slope. }\end{array}$ & $\begin{array}{l}\text { - } \text { Clear settlement } \\
\text { pattern; } \\
\text { - Fertile land; } \\
\text { - Good water supply; } \\
\text { - Paddy field still } \\
\text { - } \text { preserved; } \\
\text { - Housing density still }\end{array}$ & $\begin{array}{l}\text { - Clear settlement } \\
\text { pattern; } \\
\text { - Unique settlement } \\
\text { pattern (SMEs village) } \\
\text { - Good water supply; } \\
\text { - Housing density still } \\
\text { fine/ok. }\end{array}$ \\
\hline
\end{tabular}




\begin{tabular}{|c|c|c|c|}
\hline & & fine/oke. & \\
\hline Social & $\begin{array}{l}\text { - Strong traditional } \\
\text { institutions; } \\
\text { - Good local leadership; } \\
\text { - Good social capital; } \\
\text { - Relatively small } \\
\text { number of } \\
\text { poor/vulnerable } \\
\text { villagers. } \\
\text { - Community's } \\
\text { tolerance. }\end{array}$ & $\begin{array}{l}\text { - Strong traditional } \\
\text { institutions; } \\
\text { - Good local leadership; } \\
\text { - Good social capital; } \\
\text { - Community's tolerance. }\end{array}$ & $\begin{array}{l}\text { - Strong traditional } \\
\text { institutions; } \\
\text { - Good local leadership; } \\
\text { - Good social capital; } \\
\text { - Community's tolerance; } \\
\text { - Relatively small number } \\
\text { of poor/vulnerable } \\
\text { villagers. }\end{array}$ \\
\hline Economy & $\begin{array}{l}\text { - Strong local } \\
\text { economy/agriculture } \\
\text { and fishery; } \\
\text { - Mixed economy; } \\
\text { Tourism opportunities }\end{array}$ & $\begin{array}{l}\text { - Job Opportunities from } \\
\text { urban sectors; } \\
\text { - Mixed economy. }\end{array}$ & $\begin{array}{l}\text { - Sustainability of } \\
\text { traditional roof tile } \\
\text { industry - its } \\
\text { comparativeness; } \\
\text { - Mixed economy. }\end{array}$ \\
\hline
\end{tabular}

Source: Qualitative assessment from FGD, interviews, and secondary information

\subsection{Problems and Challenges faced by Three Villages}

As mentioned earlier, the three villages also face some pressures that threaten their sustainability. The following table summaries the pressures and challenges faced by the three villages. Such pressures and challenges, for sure, should be understood and appropriatelly respond as they would guarantee the future sustainability of the three villages.

Table 6. Problems and Challenges faced by Three Villages

\begin{tabular}{|c|c|c|c|}
\hline DIMENSION & Village: Lebih & Village: Jagapati & Village: Pejaten \\
\hline $\begin{array}{l}\text { Physical/ } \\
\text { environmental }\end{array}$ & $\begin{array}{l}\text { - Urban } \\
\text { development: road and } \\
\text { tourism facilities, } \\
\text { - } \quad \text { Seawall } \\
\text { construction; } \\
\text { - } \quad \text { New housing } \\
\text { development by } \\
\text { developer; } \\
\text { - } \quad \text { Agricultural land } \\
\text { conversion; } \\
\text { - Increasing housing } \\
\text { density; } \\
\text { Changing of } \\
\text { traditional pattern of } \\
\text { housing; } \\
\text { - Air and water } \\
\text { pollution. }\end{array}$ & $\begin{array}{l}\text { - New housing } \\
\text { development by } \\
\text { developers; } \\
\text { - } \text { Agricultural land } \\
\text { conversion } \\
\text { - More uses of pestisida; } \\
\text { - Increasing housing } \\
\text { density; } \\
\text { - Changing of traditional } \\
\text { pattern of housing; }\end{array}$ & $\begin{array}{l}\text { - New housing } \\
\text { development by } \\
\text { developers; } \\
\text { - Increasing housing } \\
\text { density; } \\
\text { - Changing of traditional } \\
\text { pattern of housing; } \\
\text { - Soil degradation; } \\
\text { - } \text { Agricultural land } \\
\text { conversion. }\end{array}$ \\
\hline
\end{tabular}




\begin{tabular}{|c|c|c|c|}
\hline Socio-cultural & $\begin{array}{ll}\text { - } & \text { Social changes; } \\
\text { - } & \text { New migrants; } \\
\text { - } & \text { New job } \\
\text { - } & \text { opportunities; } \\
\text { - } & \text { Social inequality; } \\
\text { - } & \text { HRD. }\end{array}$ & $\begin{array}{l}\text { - Job opportunities; } \\
\text { - HRD; } \\
\text { - } \quad \text { New consumerism }\end{array}$ & $\begin{array}{l}\text { - Job opportunities; } \\
\text { - HRD. }\end{array}$ \\
\hline Economy & $\begin{array}{l}\text { - } \quad \text { Economy gap } \\
\text { - } \quad \text { Tourism } \\
\text { opportunities; } \\
\text { - } \quad \text { More cash } \\
\text { economy. }\end{array}$ & $\begin{array}{l}\text { - Local economy; } \\
\text { - Access to credit; } \\
\text { - Economic value of } \\
\text { agricultural sectors. }\end{array}$ & $\begin{array}{l}\text { - Competition with } \\
\text { modern roof tile } \\
\text { industry; } \\
\text { - Market fluctuation }\end{array}$ \\
\hline
\end{tabular}

Source: qualitatif assessment from FGD, Interviews, and secondary information

\section{Conclusion: Desa-kota: An Alternatif for Sustainable Settlement?}

This research concludes four main findings. The first is that, as assumed in this research, the idea of desa-kota, firstly promoted by McGee in the early 1990s, is also existed in Bali. In this paradise island, the urban and rural tissue are strongly intertwined in a dynamic and complex system. Two settlement typologies exist in a very close proximity, the Desa (village) and the Kota (city) - The Desa-Kota. It is a mixture of agricultural and urban landscapes/fabrics which then can be appreciated as an interesting and unique cultural landscape. The Desa-Kota has urban densities, but a highly green quality. Functionally, urban settlement and rural landscape are intertwined in a dynamic and synergetic cooperation.

The second conlusion could be drawn from this research is that the Desa-Kota in Bali has some positive aspects in terms of its sustainability. There are at least six aspects of sustainability explored in this research, which includes: 1) food security; 2) poverty/vulnerability; 3) welfare and happines; 4) identitiy/proudness; 5) quality of landscape; and 6) the role of traditional institution. Although each village has differnt level of quality among these six aspects, in general, however, all have some that kind of quality. In other words, this researach has founded that those three cases have a relatively sustainability condition and prospects.

Further, the researach also found several positive factors which significantly contribute for the sustainability of cultural landscape of the desa-kota in Bali which are: 1) strong adat/traditional institution; 2) government policies; and 3) local/community leadership. These three factors are dynamically play together. Efforts to guarantee future sustainability would depend very much on how we could support such three important factors. The fact that the role of traditional institutions is very strong and significant in three cases is actually not surprising as many studies have already argued that such aspect is crucial for the whole of Balinese culture.

In addition to such positive findings, however, the researach also recognize several problems and challenges faced by the desa-kota in Bali. Among three dimensions of sustainability, economic dimention is the most challenges and problematic aspect. As far as these three villages able to appropriatelly respond such problematic and challenging aspect, their sustainability would be more guaranteed. This, in particular, relates to the idea of whether they could develop an alternative local economic resources, managed by local communities, 
and tapping the growing global market opportunities. If that condition could be achieved, the desa-kota settlement in Bali could be further develop into an alternative model for resilient and sustainable settlement.

\section{References}

Bali Environmental Agency (2015) Environmental Agency Reports: Bali Province 2015.

Cole, Stroma (2012) "A Political Ecology of Water Equity and Tourism: A Case Study From Bali", Annals of Tourism Research, Vol. 39, No. 2, pp. 1221-1241.

Firman, T. (2003) "The Spatial Pattern of Population Growth in Java, 1990-2000: Continuity and Change in Extended Metropolitan Region Formation", International Development Planning Review 25(1), pp. 53-66.

Guldin, Gregory Eliyu (1997), Desakotas and Beyond: Urbanization in Southern China. Farewell to Peasant China: Rural Urbanization and Social Change in the Late Twentieth Century . Armonk NY: M. E. Sharpe.

Haryadi, dan Setiawan. (2002), "Penyusunan Indikator-Indikator Keberlanjutan Kota di Indonesia." Dalam Jurnal Manusia dan Lingkungan. Vol. IX. No. 3.

Hebbert, Michael. (1994), Sen-biki amidst Desakota: Urban Sprawl and Urban Planning in Japan. Planning for Cities and Regions in Japan. Liverpool: Liverpool University Press.

Martopo, dan Mitchell. Eds. (1995). Bali: Balancing Environment, Economy and Culture. University of Waterloo. Department of Geography Publication Series Number 44.

McGee, Terry G. (1991), The Emergence of Desakota Regions in Asia: Expanding a Hypothesis. The Extended Metropolis: Settlement Transition Is Asia. Honolulu: University of Hawaii Press.

McGee, T.G. (2009), The Spatiality of Urbanization: The Policy Challenges of Mega-Urban and Desakota Regions of Southeast Asia, UNU-IAS Working Paper (161), United Nations University Institute of Advanced Studies.

Moench, Marcus and Dipak Gyawali. (2008), Desakota: Reinterpreting the Urban-Rural Continuum.

Parimin, Ardi Pardiman. (1986), Fundamental Study on Spatial Formation of Island Village: Emvironmental Hierarchy of Scred-Profane Concept in Bali. Disertasi tidak dipublikasikan. Osaka University, Japan.

Pelling, Mark; Mustafa, Daanish. (2010), Vulnerability, Disasters and Poverty in Desakota Systems. Environment, Politics and Development Working Paper (31), Department of Geography, King's College London

Proto Tamansari Team. (2014), Workshop Report. Manuskrip tidak dipublikasikan.

Rajendra, Anom and Nicholls, Richard. 2013. Public Space Issues in Bali Tourist Beaches. Proceedings REAL CORP 2013 Tagungsband, Rome, Italy 
Setiawan, B. (2007), "Indikator Keberlanjutan Kota di Indonesia: Studi Komparasi Empat Kota di Jawa." Dalam Jurnal Manusia dan Lingkungan. Volume 14, Noor 1.

The Desakota Study Team. (2008), Re-imagining the Rural-Urban Continuum. Understanding the role ecosystem services play in the livelihoods of the poor in desakota regions undergoing rapid change. 